\title{
ENGLISH FOR SPECIFIC PURPOSES: CHARACTERISTIC FEATURES AND CURRICULUM PLANNING STEPS
}

Summary. Knowledge of a foreign language opens new prospects of mobility and collaboration for professionals in the modern world. Education authorities recognize the increased role that foreign languages, especially English, play in the professional development of future specialists and try to introduce this subject at tertiary level. Such courses are aimed at preparing students to effectively communicate in English in their work settings. However, many university students do not have work experience in their field of specialization, or they do not know what language skills they might need in their future work. Thus, the choice of course content and teaching methods depends on the instructor who seldom has clearly defined national guidelines to rely on. The study focuses on characteristics of English for Specific Purposes (ESP). The research outlines the approaches to ESP curriculum development and planning. The paper outlines the prerequisites and methods of analysing learners' expectations and goals. The study determines what components of course content help to align aims, form, and conditions of educational activities with the students' future professional roles. The research sets to analyze ESP students' goals and expectations employing qualitative and quantitative techniques.

Keywords: English for Specific Purposes, English for Professional Purposes, English for Occupational Purposes, English for Academic Purposes, curriculum, needs analysis.

\section{Introduction}

While courses of English for Specific Purposes (ESP) are introduced in higher education institutions, theoretical framework for ESP curriculum planning is still under development. Unlike general language instructors, who have fairly detailed curricula and national guidelines, ESP teachers need to construct their own goals, objectives, and learning materials. One of the main issues in ESP course development is the focus of the syllabus and content on learners' needs. The latter are often seen as the ability to function in specific situations. However, some learners, especially university students, may find it hard to determine what language skills they need to master. On the one hand, students need the English language to fulfil academic requirements or access scientific information in their chosen field of study. On the other hand, students are future professionals, and they expect an ESP university course to prepare them to carry out professional duties in their prospective workplace. Thus, the ESP course content is to take into account the complex nature of communication needs and professionalism issues. These concerns are of particular importance today when knowledge of foreign 
languages leads to increase in academic and professional mobility opportunities. Since multilingualism is the key to understanding cultural and professional diversity, analysis of the ESP curriculum content can help instructors to tailor the course to meet learner's needs in view of intercultural approach to communication.

This research focuses on the content of ESP courses at tertiary level, looks into specific features of ESP that influence curriculum planning and content selection. Then the study attempts to determine whether the ESP course (taught in Zaporizhzhya National University), which was based on the theoretical findings presented in the paper, meets students' needs and expectations. The objectives of the study are: 1) to establish characteristics of ESP courses; 2) to study approaches to curriculum planning in ESP; 3) to determine the ESP course content; 4) to analyze students' goals and expectations in the ESP course at university.

The research used the method of literature analysis because one of the aims of the study was to determine specific features of ESP and address (theoretical) issues of ESP curriculum planning. In order to understand the goals and expectation of ESP course students, a combination of qualitative and quantitative research methods was used. Purposeful sampling and open-ended questionnaires helped to determine students' language proficiency, expectations and attitudes towards ESP instruction (Merriam, 1998). The research sought to study the students' reactions in their normal authentic context, which determined the choice of qualitative methods. The quantitative method was used to measure the significance of individual goals in ESP and establish the overall level of student satisfaction with ESP course components.

\section{Theoretical Framework}

One of the theoretical issues in teaching English for Specific Purposes is the necessity to define ESP. To determine the similarities and differences between ESP and General English Dudley-Evans and St. John (1998) put forward the list of absolute and variable characteristics that reflect specific characteristics of ESP courses. Among absolute characteristics are such features: 1) ESP is defined to meet specific needs of the learner; 2) ESP makes use of the underlying methodology and activities of the disciplines it serves; 3 ) ESP is centered on the language (grammar, lexis), skills, and discourse appropriate to these activities. Variable characteristics are: 1) ESP may be related to, or designed 
for, specific disciplines; 2) ESP may use, in specific teaching situations, a different methodology from that of General English; 3) ESP is likely to be designed for adult learners, either at tertiary level institution or in a professional work situation; 4) ESP is generally designed for intermediate or advanced students; 5) ESP course assumes that learners have some basic knowledge of the language system, but it can be used for beginners (Dudley-Evans \& St. John, 1998, pp. 4-5).

Depending on whether scholars put greater emphasis on absolute or variable features of ESP, two principal approaches to ESP can be singled out. In broad terms, ESP focuses on the specific needs of the learner and includes the skills and competencies of language usage in different contexts. According to Hutchinson and Waters, it is "not the existence of a need, but rather an awareness of the need" that sets ESP apart from General English (Hutchinson \& Waters, 1987). In this view, an ESP course should teach language usage that does not depend on a particular professional context. Educators claim that learners need flexibility in foreign language usage. Otherwise, they would not be able to perform effectively (Hutchinson \& Waters, 1988, p. 18). However, some scholars argue that a General English course follows "one size fits all" scenario. This course can be called "English for no purpose"; it teaches language for the sake of accumulating vocabulary units that a person might never need to use (Long, 2005, p. 19). The narrow approach to ESP focuses on restricted language repertoire, teaching terms, and specific discourse (Huckin, 2003; Hyland, 2003). In this view, the course emphasizes terms and concepts characteristic of a certain field of knowledge or professional sphere, for example, financial terms for managers. In practice, many ESP courses tend to shift from specialized language instruction towards the development of general English knowledge. There may be several reasons for such a change: 1) specialized ESP courses are too difficult for lower-level students; 2) such courses require research in fields other that language instruction and acquisition, and, as a consequence, are too expensive to implement; 3) specialized ESP courses can be only taught by specialists who are knowledgeable in the field other than English language (e.g., Law, Economics); 4) features of language and discourse tend to be generic, not language specific (Hyland, 2003). However, if language courses are too specific, they focus on an artificially created limited list of vocabulary units or patterns. Such courses become non-generative and form nontransferable skills; they enable learners to operate only in a formulaic or semiformulaic way. Such courses give no basis for further development, while learners 
need to be flexible and function in a wide range of situations (both professional and social) (Crombie, 1991).

An attempt to create a unified system of different ESP types, which depend on the course focus, was made by Dudley-Evans and St. John (Dudley-Evans \& St. John, 1998). Their model makes distinction between English for Academic Purposes and English for Occupational Purposes. English for Academic Purposes can be further subdivided into: 1) English (Academic) for Science and Technology, 2) English (Academic) for Legal Purposes, 3) English (Academic) for Medical Purposes, 4) English (Academic) for Management, Finance and Economics. English for Academic Purposes focuses on the development of general study abilities of analyzing and synthesizing information using a foreign language. Among specific competencies taught in such courses are: listening comprehension, note-taking, and writing in appropriate academic context (Jordan, 1997). English (Academic) for Science and Technology is an example of English for Specific Academic Purposes (in terms of Johns, 1990) and emphasizes vocabulary, discourse, and register specific to the subject of study. In such courses students develop language competencies relevant for the instruction and research in their future area of specialization (Johns, 1990). Even though English for Specific Academic Purposes uses special terms and seeks to advance students' professional development, it does not equal teaching Journalism or Economics in English. The latter are the examples of content teaching, not ESP. English for Occupational Purposes encompasses English for Professional Purposes, which deals with professional discourse, and English for Vocational Purposes, which focuses on English for mastery in craftsmanship context. The approach taken by Dudley-Evans and St. John (1998) stresses the connection between professional activity (in the model it is called 'occupation') and knowledge of the English language. English for Professional Purposes allows focusing on work-related needs making it an approach to language teaching, not the product or result of language instruction (Hutchinson $\&$ Waters, 1987). In this view, the content of language instruction is determined by the needs of the student, not the limits of a single discipline or profession. The goal of the course is teaching specific communication and language skills that would enable students to function effectively in their disciplines of specialization, professions, and workplaces. 


\section{Curriculum planning in ESP}

The study of goals, content, implementation, and evaluation of a course is crucial for ESP curriculum planning. Key features of ESP curriculum are: 1) specific tasks and focus on language in context; 2) usage of learner's background knowledge (the course assumes that students have some knowledge of both English language and their future profession); 3) operational and communicative syllabus focus; 4) learner-centeredness (Swales, 1989). In its development the ESP curriculum goes through the design, implementation, and evaluation stages (Brown, 1995; Richards, 2001). The first stage includes analyzing students' needs, designing the course syllabus, selecting methodology and materials. The second stage is ESP teaching. During the third stage the feedback from instructors, coordinators, and students is collected in order to further modify or change the course design (Dudley-Evans, 2001; Flowerdew \& Peacock, 2001; Jordan, 1997, p. 57). However, effective curriculum development does not leave the assessment till the end of the course. Observations and discussions can take place during the needs analysis, design, and implementation stages as well.

The ESP course design begins with collecting data on students' language needs and the target situations of language usage. Learners' proficiency and expectations, i.e. the level of language knowledge they expect to reach, are determined at this stage. This information can be gathered through students' selfassessment prior to instruction; monitoring professionals, who use English to perform their tasks; distributing questionnaires to key stakeholders, such as directors, to determine the language proficiency they require from their employees and outline the set of situations requiring English usage in work setting; case studies and discussions with both ESP students and instructors (Jordan, 1997, p. 39). Depending on the content and participants involved, several types of needs analyses and approaches can be singled out: target-situation, present-situation, strategy analysis, means analysis, and language audit.

The first type of needs analysis seeks to determine the set of situations where learners will have to use the English language. It focuses on the needs students have before the course starts and allows determining students' goals (Munby, 1978; Chambers, 1980; Martin, 2000). The present-situation analysis focuses on the students' language command prior to ESP instruction (Richterich \& Chancerel 1980). These two types of needs analysis are combined in learner- 
centered approach to ESP course design. The approach brings into perspective the knowledge that learners need in order to perform in a target professional situation, the language students want to learn, and inconsistencies between the aforementioned groups, i.e. gaps in learners' knowledge (Berwick, 1989; Brindley, 1989; Hutchinson \& Waters, 1987; West, 1994). Strategy analysis helps determine students' preferred styles of learning and language acquisition in order to select the most relevant teaching methods (Allwright, 1982). Means analysis takes into account the availability of equipment, materials, and teaching staff for the ESP course (Holliday \& Cooke, 1982; Swales, 1989). Language audit takes place when companies want to find out whether ESP language teaching is required for the employees, taking into consideration the types of job-related tasks the latter need to perform. This type of needs analysis seeks to determine the correlation between specific work-related situations and employees' language proficiency (Robinson, 1991).

Learners' needs analysis is followed by the ESP syllabus design which can focus on content, skills, and methods (Martin, 2000). Syllabi based on content emphasize a particular topic in language instruction, e.g., advertising, publicity, press release for students of Journalism. This type also takes into account the target situation of language usage, for students of Journalism such ESP course would include teaching English for interviewing, covering sports events or breaking news. The model includes notion-function syllabi, which rely on communicative approach to language teaching, and are aimed at providing learners with linguistic means of functioning in different communicative situations. Skills-based syllabi deal with teaching basic language competencies such as reading, writing, listening, and speaking. This type of syllabus is more relevant for an English for Specific Academic Purposes course; it can help teach students use English to prepare oral and written reports following the conventions of their chosen field of study. Method-based syllabi are organized around target tasks students will have to perform using the English language, such as dealing with customer complaints in the workplace. For example, for maritime professionals effective communication in English includes the knowledge of techniques employed in reporting and dealing with emergency situations such as fire on board or check-up problems a ship encounters in a foreign port. However, ESP course syllabi are seldom based on one particular model; most courses combine several of the presented models, such as content- and method-based or content- and skills-based ones. 
Next stage in ESP course development, such as the choice of methodology, is closely connected to the selection of course materials. There is a discussion concerning ESP methodology. Some scholars believe that since ESP courses focus on teaching language usage, not the limited repertoire of language units. Therefore, the course content should be driven by the choice of pedagogically relevant activities and not be planned around a number of relevant language units (Allwright, 1982; Piqué \& Estévez, 1991). Other researchers argue that ESP lacks its own methodology, and the courses should be organized around authentic learning materials, which represent target situations of students' language usage (Belcher, 2006; Hutchinson \& Waters, 1988; Long, 2005). However, if ESP courses focus on facilitating future professional communication in English, they should favor an integral course development approach that pays equal attention to methods and content of language instruction. Classroom activities would recreate professional or job-related contexts where language usage provides the means of solving problems and tasks. The specificity of ESP content presents a separate problem. Course materials should reflect students' interest in the target subject and introduce language using authentic material. However, genuine authenticity understood as interrelation between texts and context cannot be found in ESP classroom. Language materials taken out of the medium where they perform their communicative function become just study materials in a foreign language (Widdowson, 1979). Yet, authentic language context can be, to a certain degree, simulated in the ESP classroom using authentic tasks or modelling real-life communication situations (Belcher, 2006; Ferguson, 1997). Content-based approach can help motivate learners because they will clearly see how foreign language can be used in their professional setting. It can facilitate language instruction since students are already familiar with certain underlying concepts described in a foreign language. However, an ESP course should not be limited to specialized content or discourse. To avoid the extremes in ESP course planning, instructor should focus on three abilities: 1) ability to use special jargon, 2) ability to use general academic or business skills, 3) ability to communicate in other social settings (Gatehouse, 2001). In this view, an ESP course is a way of organizing language instruction, not the end product of language teaching as the sum of specific terms and language patterns. The content of instruction should be determined by the prospective needs of the student, not the narrow limits of a single discipline or profession. 


\section{ESP course evaluation}

In the context of educational systems of different countries a wider or narrower view on purposes of ESP instruction can be favored. In Ukraine, ESP instruction at tertiary level relies on the National Tertiary Level ESP Curriculum approved by the Ministry of Education and Science of Ukraine (2005). The Curriculum stresses the development of professional and academic skills, the need to cover professional and academic areas of subject knowledge (Ministry of Education and Science of Ukraine, 2005). Thus, two purposes in ESP instruction in the Ukrainian context can be singled out: academic and professional. Academic orientation emphasizes research purposes of language users and can be further subdivided into General English for Academic Purposes and Discipline Specific English for Academic Purposes. Professional orientation in an ESP course deals with teaching professional discourse for practical job-related tasks. It can include different subcategories, such as Business English for Professional Purposes, IT English for Professional Purposes.

The approach to ESP course planning and content described in the previous sections became the foundation for ESP teaching in Zaporizhzhya National University (Zaporizhzhya, Ukraine). A survey was conducted to determine whether such course meets the goals and expectation of ESP students. The research was carried out in two stages. During the first research stage a pilot survey was carried out to establish student goals early in the course. Based upon the principles of purposeful sampling, the researcher approached groups of first year students from the faculties of Biology, Economics, Journalism, History, Mathematics, Psychology and Pedagogy, Sociology, Physics, Slavic Linguistics, Law, and Physical Education. Students, both male and female, were aged between 16 and 18. Groups were linguistically homogeneous (Elementary level according to the Common European Framework of Reference for Languages) and of the same size (10-12 students). Linguistic homogeneity of student participants was assured, since all first year students in Zaporizhzhya National University had to take a test to determine their level of the English language knowledge before they joined a certain English class. This language testing is part of the University policy and was not carried out as part of the present research. In October 2012, after one month of ESP instruction open-ended questionnaires were distributed to the sample student groups. Research objectives and procedures were discussed with the ESP instructors, the 
heads of the faculties, and university authorities. As a consequence, the researcher was granted permission to distribute the open-ended questionnaires to students at the end of their ESP classes. Student participation in the survey was anonymous and voluntary, and 116 students (out of the total 120) took part in the research. The aim of the pilot study was to determine what students want to achieve at the end of their ESP instruction. That is why the survey was carried out among the first year students after their first month at university. At this stage students had to give their own answers (in their native language) to five questions: "What is your attitude towards studying ESP in university?"; "What English language skills will you need in future?"; "What components of language instruction are important for you (e.g., speaking, writing)?"; "Do you think you will need to use English in your future? Why?"; "What do you want to achieve at the end of the ESP course at university?" Students' answers were grouped according to the conceptual categories they represent (e.g., salary and employability are work-related concepts). Concepts mentioned by more than $50 \%$ of the participants were treated as statistically significant and were included to the new questionnaire.

The second stage of research looked into students' attitudes, needs and expectations after three terms of ESP instruction. To measure the significance of individual goals in ESP the quantitative method was used. The survey was carried out in Zaporizhzhya National University on 17-18 December 2014. 439 second year students from the faculties of Biology, Economics, Journalism, History, Mathematics, Psychology and Pedagogy, Sociology, Physics, Slavic Linguistics, Law took part in the survey. Students of Physical Education did not participate in the survey because December was the practice and internship period at their faculty. The research objectives and procedures were negotiated with heads of the faculties and university authorities. The researcher was permitted to distribute questionnaires to students at the end of the general meeting between faculty academic staff and students. Student participation in the survey was anonymous and voluntary, and 439 students out of the total 439 took part in the research. A questionnaire containing six questions, namely two statements based on a fourpoint Likert scale (ranging from 'strongly agree' to 'disagree'), two dichotomous (yes/no), and two rating scale questions, was distributed.

From the outset, students demonstrated a positive attitude towards ESP instruction, which is also evident in the fact that no learners refused to participate in the survey. The answers to the first question "What is your attitude to studying 
ESP in university? Do you support the initiative to introduce ESP at both undergraduate and postgraduate levels?" has demonstrated that most of the students $(70 \%)$ understand the role of ESP and see it as an important part of university curriculum. What is more, $43 \%$ of participants strongly agree that ESP should be part of both undergraduate and postgraduate curricula. The result shows that the second year students are aware of the role the English language plays in professional development in their chosen field of study. Therefore, the more they learn about their subject of specialization, the more complex language phenomena they need to master in order to access academic and professional information in English. Even though the answer suggests that students positively evaluate ESP instruction per se, their opinion about their own level of the English knowledge is quite controversial. The survey shows that learners' self-reported knowledge of English varies from elementary / pre-intermediate - 33\% to intermediate - $49 \%$ and upper-intermediate / advanced - $18 \%$ levels according to the Common European Framework of Reference for Languages. If compared with the results of the pilot survey, where only elementary level students participated, about one third of learners saw little or no change in their level of the English knowledge. Quantitative data suggest that learners might be struggling with the ESP course content because the course was designed mainly for pre-intermediate and intermediate students. The analysis of learners' goals in studying ESP has shown that learners expect to use English in a broad range of situations: $44.7 \%$ of students want to improve their knowledge of General English, 43.6\% plan to use English when they travel abroad. Thus, in their second year participants do not clearly see the difference between ESP and General English. They expect the ESP course to meet their more immediate needs. In this view, the special or specialized component of ESP in this year should be the development of communication competency in a specific situation, e.g., traveling, as well as enhancement of study skills. The survey has also demonstrated that $38.1 \%$ of students want to study English to improve their employment opportunities, $34.4 \%$ want to improve speaking skills, $33.3 \%$ want to find a job abroad, $31.9 \%$ want to pass English examinations to be enrolled in postgraduate courses, $22.9 \%$ want to take part in student mobility programs, $22 \%$ want to participate in conferences and summer schools. Only $4.8 \%$ of the respondents have difficulty determining the role of English in their curriculum (see Table 1). 


\section{Learners' goals in ESP instruction (one student can give several answers)}

\begin{tabular}{|c|c|}
\hline Variant of response & $N=439$ \\
\hline Improvement of general English knowledge & 44.7 \\
\hline Traveling abroad & 43.6 \\
\hline Improvement of employment opportunities & 38.1 \\
\hline Improvement of speaking skills & 34.4 \\
\hline Finding job abroad & 33.3 \\
\hline $\begin{array}{c}\text { Passing English examinations for postgraduate } \\
\text { courses }\end{array}$ & 31.9 \\
\hline Participation in student mobility programs & 22.9 \\
\hline Participation in conferences and summer schools & 22 \\
\hline No interest in studying English & 4.8 \\
\hline
\end{tabular}

There is a correlation between students' level of knowledge and their study goals. In the rating scale questions the participants had to give priority to the goals mentioned in the previous question. For the majority of students $(72 \%$ of participants) the priority in ESP university instruction is the improvement of general English knowledge. However, there is a correlation between the students' level of knowledge and their study goals established on the basis of students' selfreported level of language knowledge and their ranking of study goals. Students see ESP as a means of facilitating communication in social situations, namely in everyday communication while traveling abroad. Next place in expectations ranking belongs to language usage in job-related context, which is especially relevant for intermediate and upper-intermediate students. These groups see the connection between ESP and future professional roles and believe that knowledge of profession-related discourse can influence their employability. However, there is no direct evidence that students see the relevance of ESP for their day-to-day academic or professional activities. Opportunities to participate in academic and professional mobility programs were ranked low by the students (only $4 \%$ of participants placed these answers among the top three of their goals). The latter 
proves the point that at early stages of instruction students cannot yet see themselves in professional roles or foresee the variety of contexts in which they will need the knowledge of the English language. That is why introduction of professionally restricted vocabulary and discourse at this stage will not meet the learners' specific needs (see Table 2).

Table 2

\section{Ranking of learners' goals and self-reported level of language proficiency}

\begin{tabular}{|c|c|c|c|}
\hline Priority & $\begin{array}{l}\text { Elementary / Pre- } \\
\text { Intermediate }\end{array}$ & Intermediate & $\begin{array}{c}\text { Upper-Intermediate / } \\
\text { Advanced }\end{array}$ \\
\hline \multirow{3}{*}{1} & Expectation & Expectation & Expectation \\
\hline & $\begin{array}{c}\text { Improvement of } \\
\text { general English } \\
\text { knowledge }\end{array}$ & $\begin{array}{c}\text { Improvement of } \\
\text { general English } \\
\text { knowledge }\end{array}$ & $\begin{array}{l}\text { English for traveling } \\
\text { abroad }\end{array}$ \\
\hline & $39 \%$ & $44 \%$ & $53 \%$ \\
\hline \multirow{3}{*}{2} & Expectation & Expectation & Expectation \\
\hline & $\begin{array}{l}\text { Improvement of } \\
\text { speaking skills }\end{array}$ & $\begin{array}{c}\text { Improvement of } \\
\text { employment } \\
\text { opportunities }\end{array}$ & $\begin{array}{l}\text { English for working } \\
\text { abroad }\end{array}$ \\
\hline & $31 \%$ & $34 \%$ & $26 \%$ \\
\hline \multirow{3}{*}{3} & Expectation & Expectation & Expectation \\
\hline & $\begin{array}{c}\text { Improvement of } \\
\text { employment } \\
\text { opportunities }\end{array}$ & $\begin{array}{l}\text { Improvement of } \\
\text { speaking skills }\end{array}$ & $\begin{array}{l}\text { Improvement of general } \\
\text { English knowledge }\end{array}$ \\
\hline & $21 \%$ & $19 \%$ & $20 \%$ \\
\hline No answer & $9 \%$ & $3 \%$ & $1 \%$ \\
\hline
\end{tabular}

When the participants answered the question "What components of language proficiency are given enough or little attention in ESL classroom?" they mentioned that vocabulary development, grammar theory, grammar practice, speaking and writing skills were given enough time and attention in the classroom. However, the survey showed that students wish to practise their listening comprehension more, 
especially in the context of face-to-face communication with native speakers. It shows that at this stage of instruction (second year) students find the ability to communicate across professional boundaries more relevant than communication within discourse boundaries of their future job. It is evident in the fact that the majority of the students were satisfied with the amount of time devoted to professional communication development in the classroom (see Table 3).

\section{Classroom time spent on ESP components (\%)}

\begin{tabular}{|l|c|c|c|c|}
\hline \multirow{2}{*}{ Component } & \multicolumn{3}{|c|}{ Time spent in the classroom } \\
\cline { 2 - 5 } & $\begin{array}{c}\text { Too much } \\
\text { time }\end{array}$ & $\begin{array}{c}\text { Enough } \\
\text { time }\end{array}$ & $\begin{array}{c}\text { Little } \\
\text { time }\end{array}$ & No time \\
\hline Professional vocabulary & 19 & 50 & 24 & 7 \\
\hline General English vocabulary & 16 & 52 & 27 & 5 \\
\hline $\begin{array}{l}\text { Listening comprehension } \\
\text { (watching video) }\end{array}$ & 6 & 21 & 24 & 49 \\
\hline $\begin{array}{l}\text { Listening comprehension } \\
\text { face-to-face } \\
\text { communication with native } \\
\text { speakers) }\end{array}$ & 5 & 16 & 15 & 64 \\
\hline $\begin{array}{l}\text { Listening comprehension } \\
\text { (audio } \text { cd) }\end{array}$ & 7 & 32 & 28 & 33 \\
\hline Grammar theory & 14 & 44 & 31 & 11 \\
\hline Griting skills & 13 & 54 & 25 & 8 \\
\hline Grammar practice & 14 & 49 & 28 & 9 \\
\hline
\end{tabular}


General evaluation of the second year ESP instruction shows that most students (2.89 in average) see differences between the contents of the first and second year ESP classes. Addition of a professional component to ESP instruction is recognized by the students as means of getting access to both world and technical/professionrelated knowledge (see Table 4).

Table 4

\section{Evaluation of ESP instruction}

\begin{tabular}{|c|c|c|c|c|c|c|c|}
\hline No & Statement & $\begin{array}{c}\text { Strongly } \\
\text { agree }\end{array}$ & $\begin{array}{c}\text { Agree } \\
\text { somewhat }\end{array}$ & $\begin{array}{c}\text { Disagree } \\
\text { somewhat }\end{array}$ & $\begin{array}{c}\text { Strongly } \\
\text { disagree }\end{array}$ & Total & Average \\
\hline & $\begin{array}{c}2^{\text {nd }} \text { year ESP } \\
\text { instruction } \\
\text { differs from } \\
\text { 1st year } \\
\text { instruction }\end{array}$ & 29 & 39 & 24 & 8 & 100 & 2.89 \\
\hline $\begin{array}{c}\text { Classes focus } \\
\text { on } \\
\text { communication } \\
\text { skills } \\
\text { development }\end{array}$ & 13 & 51 & 27 & 7 & 100 & 2.73 \\
\hline & $\begin{array}{c}\text { I am satisfied } \\
\text { with ESP } \\
\text { instruction }\end{array}$ & 20 & 40 & 27 & 13 & 100 & 2.70 \\
\hline $\begin{array}{c}\text { I would not } \\
\text { change } \\
\text { anything in } \\
\text { ESP instruction } \\
\text { system }\end{array}$ & 16 & 27 & 29 & 28 & 100 & 2.29 \\
\hline
\end{tabular}

\section{Conclusions and Recommendations}

The conclusions drawn from the research suggest that ESP courses at tertiary level try to combine teaching general foreign language competencies and language use in specific academic or professional work situations. University students are the type of learners whose language needs include communication both within and across professional boundaries. Within professional boundaries learners need the English knowledge to meet the academic requirement of their study programs, access study materials, and communicate their findings. As future professionals students need to be aware of the vocabulary and communication patterns that are characteristic of their field of study. In this view, one of the main ESP characteristics is its ability to be both an approach to organizing instruction and the end product of education as the sum total of language units and communication 
strategies. ESP course development combines needs analysis, learning theories analysis, methodology development, and content selection. The techniques used in needs analysis, which can be present-situation or target situation depending on the course goals, may include interviews, surveys, and self-assessment. The content of ESP courses depends on the needs of the students and not on the framework of a particular academic discipline or professional role. Since the course is aimed at students, instructors should bear in mind that learners often do not clearly perceive their future professional roles. Content selection and methodology largely depend on instructor but they should reflect the learners' or professionals' requirements or industry needs for the English language usage.

The findings have suggested the relevance of beginning ESP teaching with English for Academic Purposes components. The latter has immediate application in student's university life and later can focus on discipline-specific academic competencies. What is more, English for Academic Purposes can be used to strengthen interdisciplinary connections and make the English language one of the means of advancing students' professional knowledge. The survey conducted in Zaporizhzhya National University among second year students has demonstrated that most learners see the importance of ESP for their instruction at tertiary level. However, their goals vary from mastering general communication skills to using English to enhance employability and professional development. The relevance of general language competencies is evident in the reported dissatisfaction with the amount of time spent developing general listening skills and wish to communicate with native speakers. In present research ESP is seen as language instruction that answers learners' demands for English usage in specific situations. University context requires the development of both general academic skills and specific research competencies in particular disciplines. The development of language proficiency for communication in the professional context and settings cannot be achieved with groups of beginners.

Some recommendations concerning the ESP course design can be made. The research advocates the division of ESP into components on the basis of the course orientation. The latter can be academic or professional. In order to meet learners' specific needs at tertiary level the ESP course content should include both general (academic) and specialized English components. The ESP course should begin in the first year as General English for Academic Purposes and develop students' listening comprehension, reading, writing, and (public) speaking in 
academic context. Then, the focus can shift towards Discipline Specific English for Academic Purposes to stress vocabulary, discourse, and register specific to the subject of study. Learners would develop language competencies relevant for the instruction and research in their future area of specialization. For example, students of Biology would become familiar with the procedures used in the academic context to describe a laboratory experiment or observation. Finally, ESP should focus on students' future profession and become both the subject that facilitates the professional development and the tool of the professional activity in the future. The approach should be goal-directed and aimed at preparing students to function adequately in target (academic and professional) situations. To realize ESP potential in students' communicative and professional development, the goals of the course should be clearly defined, discipline should focus on both broad social context of communication and communication to professional standards (Boswood, 1999). ESP classes should take into account typical situations of professional communication that motivate students to communicate in a foreign language. A more detailed present-situation needs analysis should be conducted prior to ESP instruction. Thus, the content would be tailored differently for elementary or preintermediate students, and those who have reached intermediate or upperintermediate levels. For the first group of students the emphasis should be made on English for General Academic Purposes and only then on Professional English.

Despite the endeavors made to establish the characteristics of ESP, determine course content, and analyze students' goals and expectations, two limitations are noted in the present study. Firstly, the research took into account only learners' perspective and did not look into instructors' views on ESP curriculum and planning. Secondly, no pre-test was conducted to determine the correlation between students' self-reported level of language knowledge and actual English proficiency. Therefore, further research should take into account the ESP teachers' beliefs, practices, and experience. It is suggested that class observations and interviews with both ESP learners and instructors would provide more insights.

\section{References}

Allwright, R. L. (1982). Perceiving and pursuing learners' needs. In M. Geddes \& G. Sturtridge (Eds.), Individualisation (pp. 24-31), London: Modern English Publications. 
Belcher, D. (2006). English for specific purposes: Teaching to perceived needs and imagined futures in worlds of work, study, and everyday life. TESOL Quarterly, 40, 133-156.

Berwick, R. (1989). Needs assessment in language programming: from theory to practice. In Johnson, R. K. (Ed.), The second language curriculum (pp. 4862). Cambridge: Cambridge University Press.

Boswood, T. (1999) Redefining the professional in international professional communication. Exploring the Rhetoric of International Professional Communication: An Agenda for Teachers and Researchers. In C. R. Levitt \& D. Goswami (Eds.), Exploring the Rhetoric of International Professional Communication: An Agenda for Teachers and Researchers (pp. 111-136). Amitville, N.Y.: Baywood Publishing Compny Inc. Boswood's Technical Communication Series.

Brindley, G. (1989). The role of needs analysis in adult ESL programme design. In Johnson, R. K. (Ed.), The second language curriculum (pp. 63-78). Cambridge: Cambridge University Press.

Brown, J. D. (1995). The elements of language curriculum: a systematic approach to program development. In R. Howard \& G. Brown (Eds.), Teacher education for LSP (pp. 80-89). Clevedon, England: Multilingual Matters.

Chambers, F. (1980). A re-evaluation of needs analysis in ESP. ESP Journal, 1(1), 25-33.

Crombie, W. (1991). E.S.P.: Fact or Fiction? Revista Alicantina de Estudios Ingleses, 4, 25-36.

Dudley-Evans, T. (2001). Team teaching in EAP: Changes and adaptations in the Birmingham approach. In J. Flowerdew \& M. Peacock (Eds.), Research perspectives on English for Academic purposes (pp. 225-238). Cambridge: Cambridge University Press.

Dudley-Evans, T., \& St. John, A. M. (1998). Developments in English for Specific Purposes: A Multi-Disciplinary Approach. Cambridge: Cambridge University Press.

Ferguson, G. (1997). Teacher education and LSP: The role of specialised knowledge. In R. Howard \& G. Brown (Eds.), Teacher education for LSP (pp. 80-89). Clevedon, England: Multilingual Matters. 
Flowerdew, J., \& Peacock, M. (2001). The EAP curriculum: Issues, methods, and challenges. In J. Flowerdew \& M. Peacock (Eds.), Research perspectives on English for academic purposes (pp. 177-194). Cambridge: CUP.

Holliday, A. R., \& Cooke, T.M. (1982). An ecological approach to ESP. In A. Waters (Ed.), Issues in ESP (Lancaster practical papers in English language education 5) (pp. 124-144). Oxford: Pergamon Press.

Huckin, T. (2003). Specificity in LSP. IBERICA, 5, 3-17.

Hutchinson, T., \& Waters, A. (1987). English for Specific Purposes: a LearningCentered Approach. Cambridge: Cambridge University Press.

Hutchinson, T., \& Waters, A. (1988). ESP at the Crossroads. In J. Swales (Ed.), Episodes in English for Specific Purposes: A Source and Reference Book on the Development of English for Science and Technology (pp. 174-185). New York: Prentice Hall.

Hyland, K. (2003). Genre-based pedagogies: a social response to process. Journal of Second Language Writing, 12(1), 17-29.

Johns, A. (1990). ESP in the USA: State of the Art. Proceedings of the $2^{\text {nd }}$ Latin American ESP Colloquium. Santiago de Chile, 1-13.

Jordan, R. R. (1997). English for academic purposes: A guide and resource book for teachers. Cambridge: Cambridge University Press.

Long, M. (2005). Second language needs analysis. Cambridge, UK: Cambridge University Press.

Martin, E. (2000). Designing and Implementing a French-for-Specific-Purposes (FSP) Program: Lessons Learned from ESP. Global Business Languages, 5. Retrieved from http://docs.lib.purdue.edu/gbl/vol5/iss1/3.

Merriam, S. B. (1998) Qualitativeresearch and case study applications in education. San Fransisco: Jossey-Bass.

Ministry of Education and Science of Ukraine (2005). English for Specific Purposes (ESP). National Curriculum for Universities. Retrieved from im.nmu.org.ua/ua/library/national_esp_curriculum.pdf.

Munby, J. (1978). Communicative Syllabus Design. Cambridge: CUP.

Piqué, J., \& Estévez, N. (1991). Syllabus planning in English for the Health Sciences. In M. McGinity Travers et al. (Eds.), Lenguas aplicadas a las ciencias y la tecnologia (pp. 124-135). Badajoz: Universidad de Extremadura \& Universidade de Évora. 
Richards, J. (2001). Curriculum development in language teaching. Cambridge: Cambridge University Press.

Richterich, R. Chancerel, J. L. (1980). Identifying the Needs of Adults Learning a Foreign Language. Oxford: Pergamon Press.

Robinson, P. (1991). ESP Today: A Practitioner's Guide. London: Prentice Hall.

Swales, J. M. (1989). Service English program design and opportunity cost. In Johnson (Ed.), The second language curriculum (pp. 79-90). Cambridge: Cambridge University Press.

West, R. (1994). Needs analysis in language teaching. Language teaching, 27/1, $1-19$.

Widdowson, H. (1979). Explorations in applied linguistics. Oxford, England: Oxford University Press.

\section{Anastasiia Belyaeva}

Zaporožès nacionalinis universitetas, Ukraina; anabelwhite@gmail.com

\section{ANGLY KALBA SPECIALIEMS TIKSLAMS: BŪDINGI BRUOŽAI IR CURRICULUM PLANAVIMO ŽINGSNIAI}

Santrauka. Užsienio kalbu mokèjimas šiuolaikiniame pasaulyje atveria naujas specialistu mobilumo ir bendradarbiavimo galimybes. Ugdymo srities ekspertai pripažista, kad sustiprèjęs užsienio kalbu, ypač anglu kalbos, vaidmuo yra itin svarbus ateities specialistu profesinio tobulejimo srityje ir stengiasi idiegti ši dalyką aukštojo mokslo studiju programose. Tokiu dalyku tikslas - parengti studentus efektyviai komunikacijai anglu kalba ju darbo aplinkoje. Vis dèlto daugelis universitetu studentu neturi darbo patirties savo specialybès srityje arba nežino, kokiu kalbiniu igūdžiu jiems gali prireikti ateityje profesinèje veikloje. Taigi dalyko turinio ir mokymo metodu parinkimas priklauso nuo dèstytojo, kuris dažnai neturi aiškiai apibrèžtu valstybiniu gairiu. Šiame tyrime pateikiami anglu kalbos specialiems tikslams (ESP) bruožai, nagrinejami ESP mokymo planu kūrimo aspektai, metodai ir reikalavimai besimokančiuju lūkesčiu ir tikslu analizei. Tyrimo procese nustatyta, kokie kurso turinio komponentai leistu suvienodinti ugdymo veiklu tikslus, formas ir salygas su studentu profesiniais vaidmenimis ateityje. ESP studentu tikslai ir lūkesčiai analizuojami panaudojant kokybini ir kiekybini tyrimo metodus.

Pagrindinès sąvokos: anglu kalba specialiems tikslams, anglu kalba profesiniams tikslams, curriculum, poreikiu analizè. 